\title{
Nuclear transplantation of embryonic stem cells in mice
}

\author{
Y. Tsunoda and Y. Kato \\ Laboratory of Animal Reproduction, College of Agriculture, Kinki University, Nara, Japan
}

\begin{abstract}
The developmental ability of enucleated mouse eggs that had received embryonic stem cells was examined. In a preliminary study, none of the reconstituted eggs formed a nucleus using inactivated Sendai virus (HVJ) after activation with ethanol. DC pulses were applied at 100 or $140 \mathrm{~V} \mathrm{~mm}^{-1}$ in addition to this treatment. After electrofusion, $29-40 \%$ of reconstituted eggs formed nuclei and $41-60 \%, 25-44 \%, 12-24 \%$ and $12-18 \%$ developed to two-cell and fourcell and morulae and blastocysts, respectively. The ability of reconstituted eggs to form blastocysts did not depend on the age of recipient eggs, except in cases of very young and very old eggs. Although implantation sites were observed, no live fetuses were obtained after the transfer of reconstituted eggs to the recipients.
\end{abstract}

\section{Introduction}

Embryonic stem cells can be established from blastocysts and maintained in culture in vitro as a pluripotent cell line. Embryonic stem cells have been injected into blastocysts or aggregated with eight-cell embryos to produce chimaeras (Bradley et al., 1984; Lallemand and Brulet, 1990) and some are germ-line chimaeras. Although embryonic stem cells have thus been effectively used for introducing genes into animals (Robertson et al., 1986), it takes a long time to obtain homologous transgenic animals since at least two matings are necessary. Nagy et al. (1990) reported that live fetuses with entirely embryonic stem cell genotype were obtained by aggregation with tetraploid embryos, but died shortly after birth. If embryonic stem cells develop directly into young rather than through chimaeras, if they are totipotent, it should be possible to shorten the time required for obtaining transgenic mice. Moreover, the individuals obtained should be a clone.

The present study was undertaken to examine the developmental ability of nuclear transferred mouse eggs with embryonic stem cells.

\section{Materials and Methods}

\section{Preparation of ES cells}

The ES cell line (FI/I) used in the present study was established (Tokunaga and Tsunoda, 1992) using the technique described by Doetschman et al. (1985) and contained euploid $X Y$ chromosomes. The blastocysts obtained on day 3.5 after coitus from $\mathrm{C} 57 \mathrm{BL} / 6$ strain female mice mated with CBA males were used to establish the ES cell line. The cells were frozen at $-80^{\circ} \mathrm{C}$ or in liquid nitrogen after $11-20$ passages. The frozenthawed cells were washed and cultured for 1 to 2 days before use. The cells were treated with trypsin and gently disaggregated into single cells before nuclear transplantation. The ES

Received 15 September 1992. cells at the same number of passages aggregated with eight-cell embryos to produce chimaeras at high frequency (more than $50 \%$ ) and most were germ-line chimaeras (Kato and Tsunoda, unpublished).

\section{Nuclear transplantation}

Unfertilized eggs were obtained from superovulated $F_{1}$ (C57BL/6 $\times$ CBA) females 15-17 h after injection of 5 iu hCG. The zonae pellucidae of eggs were cut along $10-20 \%$ of their circumference as described by Tsunoda et al. (1988). The eggs were stained with Hoechst $33342\left(2 \mu \mathrm{g} \mathrm{ml}^{-1}\right)$ for $5 \mathrm{~min}$ and incubated with $5 \mu \mathrm{g}$ cytochalasin $\mathrm{B} \mathrm{ml}{ }^{-1}$ and $3 \mu \mathrm{g}$ nocodazole $\mathrm{ml}^{-1}$ (Aldrich Chemical Company, WI) for $15 \mathrm{~min}$. The second metaphase chromosomes were mechanically removed under a fluorescence microscope within $15 \mathrm{~s}$ according to the procedures reported by Tsunoda et al. (1988). By these procedures, the chromosomes could be completely removed and the first polar body was also removed.

In a preliminary study, a single embryonic stem cell (Fig. 1) was fused with enucleated eggs at the second metaphase by inactivated Sendai virus (HVJ) as described by Tsunoda $e t$ al. (1989). However, none of the eggs formed a nucleus after activation with ethanol. Phytohaemagglutinin (PHA) was used to facilitate fusion of embryonic stem cells with eggs; a single embryonic stem cell was drawn into an injection pipette, moved to PHA solution in M2 (Fulton and Whittingham, 1978) and washed in and out several times before drawing a small volume of $\mathrm{HVJ}$ ( 2600 haemagglutinating activity units $\mathrm{ml}^{-1}$ ) (Kato and Tsunoda, 1992). Activation was induced within $30 \mathrm{~min}$ after embryonic stem cell transfer by exposure to $7 \%$ ethanol for $7 \mathrm{~min}$ at room temperature (Cuthbertson, 1983). Enucleated eggs with an ES cell were subjected to electrical stimulation to facilitate the fusion and activation of fused eggs. The nuclear transferred eggs were equilibrated in Zimmerman's cell fusion medium $\left(0.28\right.$ mol sucrose $1^{-1}, 0.5 \mathrm{mmol} \mathrm{Mg}\left(\mathrm{C}_{2} \mathrm{H}_{3} \mathrm{O}_{2}\right)_{2} \mathrm{H}_{2} \mathrm{Ol}^{-1}$, $0.1 \mathrm{mmol} \mathrm{Ca}\left(\mathrm{C}_{2} \mathrm{H}_{3} \mathrm{O}_{2}\right)_{2} \mathrm{1}^{-1}, 0.1 \mathrm{mmol} \mathrm{K} \mathrm{HPO}_{4} \mathrm{l}^{-1}, 0.1 \mathrm{mmol}$ glutathione $\mathrm{l}^{-1}, 0.01 \mathrm{mg} \mathrm{BSA} \mathrm{ml}^{-1}$ and $1 \mathrm{mmol} \mathrm{K}_{2} \mathrm{HPO}_{4} \mathrm{l}^{-1}$ (Wolfe and Kraemer, 1992) and transferred to a drop of fusion 
Table 1. Effects of intensity of DC pulses on activation and the development of enucleated mouse eggs receiving embryonic stem cells

\begin{tabular}{|c|c|c|c|c|c|}
\hline \multirow{2}{*}{$\begin{array}{l}\text { Voltage } \\
\text { of pulses } \\
\left(\mathrm{V} \mathrm{mm}^{-1}\right)\end{array}$} & \multirow{2}{*}{$\begin{array}{l}\text { Duration } \\
\text { of pulses } \\
\quad(\mu s)\end{array}$} & \multirow{2}{*}{$\begin{array}{c}\text { Number } \\
\text { of eggs } \\
\text { used }\end{array}$} & \multirow{2}{*}{$\begin{array}{l}\text { Number of } \\
\text { eggs with a } \\
\text { nucleus }(\%)\end{array}$} & \multicolumn{2}{|c|}{$\begin{array}{l}\text { In vitro development of } \\
\text { eggs with nucleus (\%) }\end{array}$} \\
\hline & & & & 2-cell & Blastocyst \\
\hline \multirow[t]{2}{*}{100} & 30 & 62 & $26(42)$ & $10(38)$ & $4(15)$ \\
\hline & 50 & 100 & $22(22)$ & $11(50)$ & $6(27)$ \\
\hline \multirow[t]{3}{*}{140} & 30 & 56 & $15(27)$ & $10(67)$ & $1(7)$ \\
\hline & 50 & 94 & $19(20)$ & $10(53)$ & $3(16)$ \\
\hline & 100 & 55 & $10(18)$ & $6(60)$ & 0 \\
\hline
\end{tabular}

Table 2. Effects of age of recipient egg on the activation and development of enucleated mouse eggs receiving embryonic stem cells

\begin{tabular}{|c|c|c|c|c|c|c|c|c|c|c|}
\hline \multirow{2}{*}{$\begin{array}{l}\text { Age of } \\
\text { oocytes } \\
\text { (h after } \\
\text { (hCG) }\end{array}$} & \multirow{2}{*}{$\begin{array}{l}\text { Number of } \\
\text { eggs with } \\
\text { nucleus/ } \\
\text { Total (\%) }\end{array}$} & \multicolumn{5}{|c|}{ Number of eggs $(\%)$ with } & \multicolumn{4}{|c|}{$\begin{array}{l}\text { In vitro development of eggs } \\
\text { with nucleus(ei) (\%) }\end{array}$} \\
\hline & & 1 nucleus & $\begin{array}{l}\text { I nucleus with } \\
\text { polar body }\end{array}$ & 2 nuclei & $\begin{array}{l}\text { Immediate } \\
\text { cleavage }\end{array}$ & Fragment & 2-cell & 4-cell & Morula & Blastocyst \\
\hline $13-14$ & $6 / 111 \quad(5)$ & $4(67)$ & $2(33)$ & & & $\begin{array}{l}0 \\
0\end{array}$ & $\begin{array}{ll}1 & (25) \\
0 & \end{array}$ & 0 & 0 & 0 \\
\hline $18-19$ & $45 / 154(29)$ & $25(56)$ & $19(42)$ & $I(2)$ & & $\begin{array}{l}0 \\
0 \\
0\end{array}$ & $\begin{array}{r}11(44) \\
15(79) \\
1(100)\end{array}$ & $\begin{aligned} 9 & (36) \\
11 & (58) \\
0 & \end{aligned}$ & $\begin{array}{l}4(16) \\
7(37)\end{array}$ & $\begin{array}{l}3(12) \\
5(26)\end{array}$ \\
\hline $25-26$ & $60 / 158(38)$ & $44(73)$ & $12(20)$ & $3(5)$ & $1(2)$ & $\begin{array}{l}0 \\
0 \\
0 \\
0\end{array}$ & $\begin{array}{rr}12 & (27) \\
9 & (75) \\
3 & (100) \\
-\end{array}$ & $\begin{array}{rr}10 & (23) \\
3 & (25) \\
3 & (100) \\
1 & (100)\end{array}$ & $\begin{array}{l}4 \quad(9) \\
2(17) \\
2(67) \\
0\end{array}$ & $\begin{array}{l}4 \quad(9) \\
2(17) \\
1(33)\end{array}$ \\
\hline $25-26^{*}$ & $213 / 556(38)$ & $71(33)$ & $133(62)$ & $4(2)$ & $5(2)$ & $\begin{array}{l}0 \\
0 \\
0 \\
0\end{array}$ & $\begin{array}{cc}19 & (27) \\
70 \quad(53) \\
4(100) \\
-\end{array}$ & $\begin{array}{rr}8 & (11) \\
42 & (32) \\
4 & (100) \\
0 & \end{array}$ & $\begin{array}{r}6(8) \\
28(21) \\
3(75)\end{array}$ & $\begin{array}{r}5(7) \\
23(17) \\
1(25)\end{array}$ \\
\hline $28-29^{*}$ & $25 / 63 \quad(40)$ & $12(48)$ & $13(52)$ & & & $\begin{array}{l}0 \\
0\end{array}$ & $\begin{array}{rr}3 & (25) \\
10 & (77)\end{array}$ & $\begin{array}{ll}3 & (25) \\
5 & (38)\end{array}$ & $\begin{array}{lr}1 & (8) \\
2 & (15)\end{array}$ & $\begin{array}{lr}1 & (8) \\
2 & (15)\end{array}$ \\
\hline $31-32^{*}$ & $? / 95$ & & & & & $59(62)$ & 0 & & & \\
\hline $41-42^{*}$ & $? / 111$ & & & & & $41(37)$ & 0 & & & \\
\hline
\end{tabular}

The table shows the number of eggs at each specific stage of development as the proportion of eggs in which nuclei were observed 6-7 h after fusion. *These oocytes were recovered and enucleated at 21 to $22 \mathrm{~h}$, but used at the time indicated.

medium in a fusion chamber composed of two wire electrodes mounted on a glass slide $1000 \mu \mathrm{m}$ apart. The enucleated eggs and embryonic stem cell were aligned by pipetting and fusion was induced by DC pulses of 100 or $140 \mathrm{~V} \mathrm{~mm}^{-1}$ for 30,50 or $100 \mu \mathrm{s}$. The enucleated eggs with ES cells were then washed with M2 and cultured in M16 medium (Whittingham, 1971) in $5 \% \mathrm{CO}_{2}$ and $95 \%$ air at $37^{\circ} \mathrm{C}$. They were again subjected to the same DC pulse $1 \mathrm{~h}$ after the first treatment (Collas and Robl, 1991) and then cultured for 5 to $6 \mathrm{~h}$ and examined for the formation of a nucleus. Eggs with a nucleus(ei) were further cultured for 4 to 5 days. The development of nuclear transferred eggs was examined daily to determine the number of eggs at specific stages of development.
To examine the effects of ageing of recipient oocytes, the following oocytes were used: those recovered at (1) $13-14 \mathrm{~h}$, (2) 18-19 h, (3) 25-26 h after injection of hCG and immediately enucleated; those recovered and enucleated at 21 to $22 \mathrm{~h}$ after hCG but used as recipient oocytes at (4) $25-26 \mathrm{~h},(5) 28-29 \mathrm{~h}$, (6) $31-32 \mathrm{~h}$ and (7) $4 \mathrm{I}-42 \mathrm{~h}$ after hCG injection.

Some eggs that developed to the blastocyst stage were transferred to the oviducts of day 1 pseudopregnant CD-1 strain females and killed on days 12.5 and 18.5 to determine the presence of implantation sites and fetuses, or were transferred to pregnant $\mathrm{CD}-1$ strain females mated with $\mathrm{F}_{1}(\mathrm{C} 57 \mathrm{BL} / 6 \times \mathrm{CBA})$ males to monitor the success of pregnancy (McLaren and Michie, 1956), which was subsequently allowed to proceed to term. 

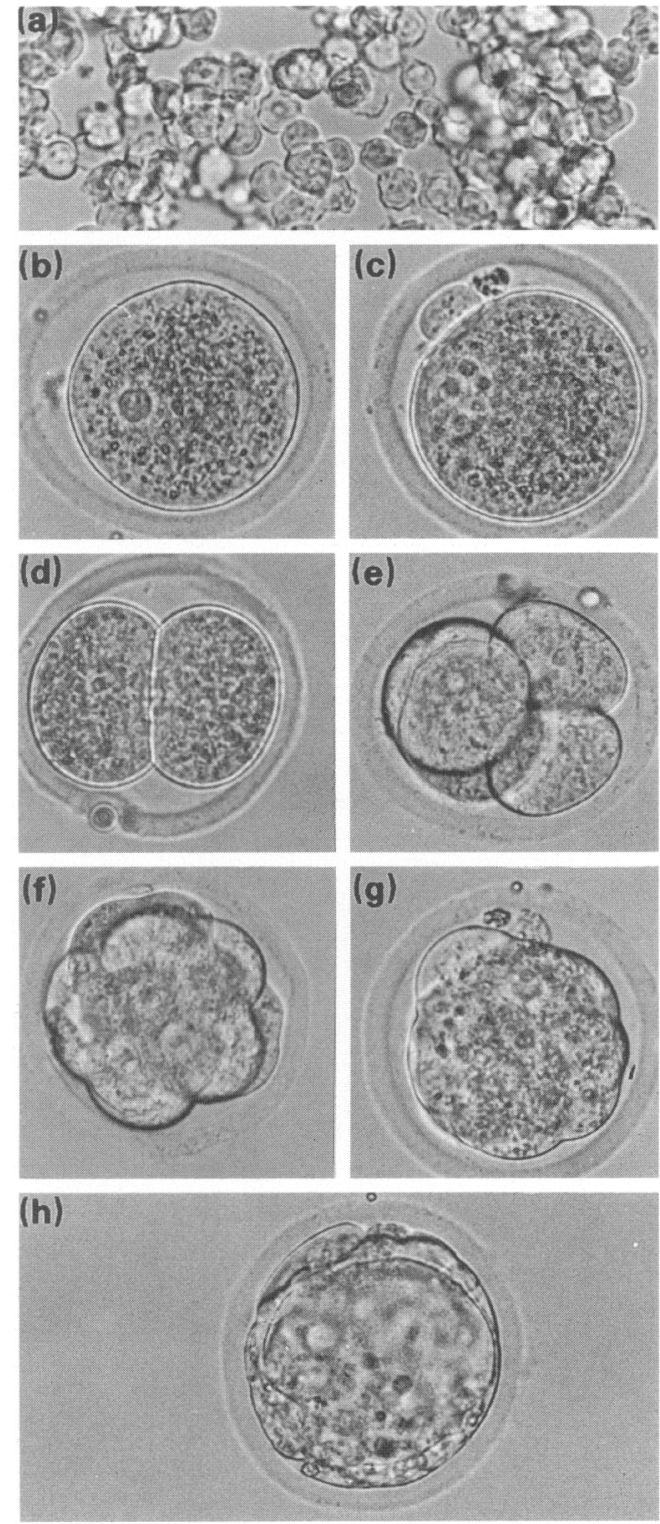

Fig. 1. (a) ES cells before nuclear transfer are shown. (b) and (c) Enucleated eggs at the second metaphase are fused with a single ES cell, and one nucleus was formed without (b) or with (c) a polar body. (d-h) Development in vitro of enucleated eggs receiving an ES cell is shown: (d) two-cell stage; (e) four-cell stage; ( $\mathrm{f}$ eight-cell stage; (g) morula and (h) blastocyst.

\section{Statistical analysis}

The data were analysed by $\chi^{2}$ analysis.

\section{Results}

Eggs exposed to DC pulses at $100 \mathrm{~V} \mathrm{~mm}^{-1}$ for $30 \mu$ s were activated more frequently $(P<0.01-0.001)$ than those in the other groups ( $42 \%$ versus 18 to $27 \%$, respectively) (Table 1 ). The proportion of eggs the embryonic stem cells of which were degenerated was high at $140 \mathrm{~V} \mathrm{~mm}^{-1} \mathrm{DC}$ pulses applied for 50 and $100 \mu \mathrm{s}$. The proportion of eggs that had ES cells and developed into blastocysts was not significantly different except in cases of treatment with $140 \mathrm{~V} \mathrm{~mm}^{-1}$ for $100 \mu \mathrm{s}$.

The proportion of eggs with a nucleus(ei) was low in eggs used at 13-14 h after hCG, but not different from those used at 18-29 h after hCG (Table 2). A large proportion of reconstituted eggs used at $31-32 \mathrm{~h}$ and $41-42 \mathrm{~h}$ after hCG injection degenerated $5-6 \mathrm{~h}$ after activation. The proportion of reconstituted eggs that had two nuclei or showed immediate cleavage was low in all groups. The proportion of eggs that formed one nucleus with one polar body (Fig. Ib) was higher in groups IV and $\mathrm{V}$ than in groups I-III. The ability of reconstituted eggs with a polar body to develop to blastocysts was high in all groups $(15-26 \%)$ compared with that of eggs without a polar body (Fig. Ic to $12 \%$ ). Twenty-three blastocysts that developed from eggs that received ES cells were transferred to fifteen pregnant $\mathrm{CD}-\mathrm{I}$ females mated with the same strain males but none produced young from reconstituted eggs. Eighteen reconstituted blastocysts were transferred to four pseudopregnant recipients and one had two implantation sites but no fetus on day 18.5. Fifteen reconstituted blastocysts were also transferred to five pseudopregnant recipients and three of eight had implantation sites, but no fetuses could be detected on day 12.5 .

\section{Discussion}

In a preliminary study, the nuclear transfer of embryonic stem cells into enucleated eggs was conducted by the same procedures as those for mouse primordial germ cells (Tsunoda et al., 1989; Kato and Tsunoda, 1992). However, none formed a nucleus by HVJ following activation with ethanol. Electrofusion in addition to HVJ and ethanol treatment was thus conducted.

After electrofusion, $29-40 \%$ of enucleated eggs that had received embryonic stem cells formed a nucleus and $41-60 \%$, $25-44 \%, 12-24 \%$ and $12-18 \%$ developed to the two-cell stage, four-cell stage, morula and blastocyst, respectively. As far as we know, this is a first report on nuclear transfer of mouse embryonic stem cells. The chromosomes at the second metaphase could be completely removed (Tsunoda et al., 1988), thus ruling out the possibility that the blastocysts were of parthenogenetic origin.

Live fetuses were not obtained after transfer of reconstituted blastocysts to pregnant or pseudopregnant recipients. In the present study, only three to five eggs were transferred to each pseudopregnant recipient owing to the limited number of blastocysts that could be obtained in one day. However, this should not have affected their developmental potential, since McLaren (1970) reported that the number of eggs transferred into pseudopregnant mice (in the range 2-12) had no effect on the number that implanted. Although $70 \%$ of the embryonic stem cells, F1/1, had 40 chromosomes (Tokunaga, unpublished), chromosome abnormality of embryonic stem cells may explain the low ability of eggs to develop into blastocysts in vitro and the failure of enucleated eggs receiving embryonic stem cells to form fetuses. Although it is possible that there are irreversible epigenetic differences among nuclei of various stages, the most plausible explanation for failure would be the inadequency of nuclear transfer techniques. From previous studies (Tsunoda et al., 1987a,b) in which young were obtained after transfer of 
isolated blastomeres of eight-cell mouse embryos aggregated with parthenogenone or enucleated two-cell embryos receiving the nucleus of eight-cell embryos, it is clear that nuclei of eightcell mouse embryos are totipotent. However, the fact that enucleated mouse unfertilized eggs that had received a nucleus from an eight-cell embryo did not develop into blastocysts (Tsunoda et al., 1989; Kono et al., 1991) indicates that the physiological conditions of the nucleus and cytoplasm were not suitable in the mouse nuclear transfer system. Totipotency of inner cell mass nuclei has not been confirmed in mice, although a few enucleated eggs receiving inner cell mass nuclei have been shown to develop to blastocysts (Tsunoda et al., 1989; Kono et al., 1991).

In contrast to mouse eggs, enucleated sheep eggs fused with inner cell mass cells of blastocysts developed into lambs after transfer to recipients (Smith and Wilmut, 1989). The finding that enucleated mouse eggs receiving ES cells developed into blastocysts indicates that enucleated sheep eggs reconstituted with ES cells, if established, could possibly develop into young.

The proportion of reconstituted eggs receiving ES cells that developed into blastocysts did not depend on the age of a recipient egg, except in cases of very young and very old eggs. In contrast to the present results, the developmental ability of enucleated bovine oocytes receiving a blastomere of eight- to 32-cell stage embryos was high when aged oocytes were used (Yang et al., 1991; Leibfried-Rutledge et al., 1992). Although the reason for this discrepancy is not clear, differences in the duration of each stage of the cell cycle between mouse ES cells and bovine embryonic nuclei may be a partial explanation. The importance of synchronization of the cell cycle between the donor nucleus and the recipient cytoplasm has been pointed out in the development of nuclear transferred eggs (Smith et al., 1988; Collas et al., 1992a,b). Collas et al. (1992a) reported the enhanced rate of development of enucleated rabbit eggs receiving 32-cell stage nucleus to blastocysts with donor nuclei in the G1 phase ( $71 \%$ ), as opposed to the late S phase (15\%). An unsuitable stage of the cell cycle of a donor nucleus has also been shown to lead to abnormal chromosome constitution in nuclear transferred eggs (Collas et al., 1992b). Techniques for the development of reconstituted eggs with ES cells in vitro and for obtaining young following transfer to recipients should be improved.

This study was supported by a grant from the Japanese Ministry of Science and Technology (Developmental Biotechnology), Human Science Foundation and Sasakawa Scientific Research Grant.

\section{References}

Bradley A, Evans M, Kaufman MH and Robertson E (1984) Formation of germline chimaeras from embryo derived teratocarcinoma cell lines Nature 309 255-256

Collas P and Robl JM (1991) Relationship between nuclear remodelling and development in nuclear transplant rabbit embryos Biology of Reproduction 45 $455-465$
Collas P, Balise JJ and Robl JM (1992a) Influence of cell cycle stage of the donor nucleus on development of nuclear transplant rabbit embryos Biology of Reproduction 46 492-500

Collas P, Pinto-Correia C, De Leon AP and Robl JM (1992b) Effect of donor cell cycle stage on chromatin and spindle morphology in nuclear transplant embryos Biology of Reproduction 46 501-511

Cuthbertson KSR (1983) Parthenogenetic activation of mouse oocytes in vitro with ethanol and benzylalcohol Journal of Experimental Zoology 226 311-314

Doetschman TC, Eistetter H, Katz M, Shmidt W and Kemler R (1985) The in vitro development of blastocyst-derived embryonic stem cell lines; formation of visceral yolk sac, blood islands and myocardium Journal of Embryology and Experimental Morphology 87 27-45

Fulton BP and Whittingham DG (1978) Activation of mammalian oocytes by intracellular injection of calcium Nature 273 149-151

Kato $Y$ and Tsunoda $Y$ (1992) Several factors affecting the nuclear formation after nuclear transfer of male fetal germ cells into enucleated eggs in the mouse Japanese Joumal of Fertility and Sterility 37 375-379

Kono T, Kwon OY and Nakahara T (1991) Development of enucleated mouse oocytes reconstituted with embryonic nuclei Journal of Reproduction and Fertility 93 165-172

Lallemand $Y$ and Brulet $P$ (1990) An in situ assessment of the routes and extents of colonisation of mouse embryo by embryonic stem cells and their descendent Development 110 1241-1248

Leibfried-Rutledge ML, Northey DL, Nuttleman PR and First NL (1992) Processing of donated nucleus and timing of post-activation events differ between recipient oocytes 24 or $42 \mathrm{hr}$ of age Theriogenology 37244 (Abstract)

McLaren A (1970) The fate of very small litters produced by egg transfer in mice Journal of Endocrinology $4787-94$

McLaren A and Michie D (1956) Studies on the transfer of fertilized mouse eggs to uterine foster mothers Joumal of Experimental Biology 33 394-416

Nagy A, Gocza E, Diaz EM, Prideaux VR, Ivanyi E, Markkula M and Rossant J (1990) Embryonic stem cells alone are able to support fetal development in the mouse Development 110 815-821

Robertson ER, Bradley A, Kuehn M and Evans M (1986) Germ line transmission of genes introduced into cultured pluripotent cells by retroviral vector. Nature 323 445-448

Smith LC and Wilmut I (1989) Influence of nuclear and cytoplasmic activity on the development in vivo of sheep embryos after nuclear transplantation Biology of Reproduction 40 1027-1035

Smith LC, Wilmut I and Hunter RHF (1988) Influence of cell cycle stage at nuclear transplantation on the development in vitro of mouse embryos Journal of Reproduction and Fertility 84 619-624

Tokunage $T$ and Tsunoda $Y$ (1992) Efficacious production of viable germline chimera between embryonic stem (ES) cells and 8-cell stage embryos Development Growth and Differentiation 34 561-566

Tsunoda Y, Yasui T, Okubo Y, Nakamura K and Sugie T (1987a) Development of one or two blastomeres from eight-cell mouse embryos to term in the presence of parthenogenetic eggs Theriogenology 28 615-623

Tsunoda Y, Yasui T, Shioda Y, Nakamura K, Uchida T and Sugie T (1987b) Fullterm development of mouse blastomere nuclei transplanted into enucleated two-cell embryos journal of Experimental Zoology 242 147-151

Tsunoda Y, Shioda Y, Onodera M, Nakamura K and Uchida T (1988) Differential sensitivity of mouse pronuclei and zygotes cytoplasm to Hoechst staining and ultraviolet irradiations Journal of Reproduction and Fertility 82 173-178

Tsunoda Y, Tokunaga T, Imai H and Uchida T (1989) Nuclear transplantation of male primordial germ cells in the mouse Development $107407-411$

Whittingham DG (1971) Culture of mouse ova Journal of Reproduction and Fertility Supplement 14 7-21

Wolfe BA and Kraemer DC (1992) Methods in bovine nuclear transfer Theriogenology 37 5-15

Yang X, Jiang S and Foote RH (1991) Age dependent activation, enucleation and nuclear transfer of bovine oocytes matured in vitro and in vivo Biology of Reproduction 44141 (Abstract) 